\title{
Investigation of the Mutual Influence between a Polluted River and its Hyporheic
}

\author{
Milan Meŝtrov \\ and Romana Lattinger-Penko*
}

\begin{abstract}
SUMMARY
This paper describes investigations of fundamental biological and pratical importance. Interstitial subterranean water (hyporheic) which is near a polluted river in a plain is the subject of the study. The water is becoming increasingly important as a source of drinking water. The relation of the hyporheic water to the physical, chemical, bacteriological and faunistic characteristics of the river is discussed.
\end{abstract}

\section{INTRODUCTION}

The object of this paper is to present our studies on interstitial subterranean waters, those filling tiny crevices among particles of stream bottoms and beaches as well as sand and gravel alluvial sediments of river valleys, i.e. potamostygal, mixopotamostygal, and eustygal (Husmann, 1975).

The phenomenon of life and its features, along with the increasing importance of interstitial subterranean waters as a source of drinking water, involve biological and ecological studies as well as hydrogeological, chemical, physical, and medical ones.

Quantity, physico-chemical characteristics, and distribution of these subterranean waters are relatively well known on both a regional and world scope. Although still in the initial stages, research on the dynamics of composite ecological processes are progressing. Research on natural habitats has scientific as well as practical values, and some experiments have already been performed (Husmann, 1968, 1971, 1974/75; Ritterbusch; 1976).

Ecological research on interstitial waters includes questions concerning: the composition of the biocenosis and the relation of its terrestrial and subterranean faunistic elements; the relations between the structure of biocenoses and the physical features of substratum, e.g., volumes of intergranular spaces and their practicability for water circulation, water temperature and $\mathrm{pH}$; and the relation between biocenoses, water chemistry and the quantity of existing food (Lüpkes, 1976; Husmann, 1968). Studies of vertical and horizontal distributions and density of populations depending on ecological and

\footnotetext{
* Department of Zoology, Faculty of Natural Sciences and Mathematics, University of Zagreb.
} 
other factors have also been carried out (Husmann, 1974/75; Danielopol, 1976; Mestrov, et al., 1976a).

The attachment of certain subterraneán organisms (stygobionts), i.e., of their communities to the biotopes of specific characteristics, also serves as an indicator of the quality of underground waters for human consumption (Husmann, 1964; Spangenberg, 1973).

Since phreatic waters serve as drinking water, understanding of the connections and mutual influences of surface waters (particularly polluted ones) to subterranean waters is of special significance as allochthonous environmental pollution develops. For this purpose various indicators have been used, such as fluorescent tracers (Giammona, 1973) and radioactive tracers (Kubelka, personal communication). Control of changing physico-chemical and biological parameters through a system of permanent bores (Husmann, 1974/75), or provisional ones, are also used (Bou and Rouch's method).

The results presented here were obtained in studies completed during 1973 and 1974 in the Sava river valley, not far from Zagreb (the Jankomir bridge), where the relatively shallow and fast moving river circulates over thick alluvial sediments of sand and gravel watered by phreatic flows.

The aim of our studies was to learn the condition, quality, connections, and mutual influence of the river and surrounding subterranean hyporheic waters (potamostygal and mixo-potamostygal) with the phreatic water (eustygal) in this contact zone, as well as possible infiltration of surface water into the phreatic, and viceversa.

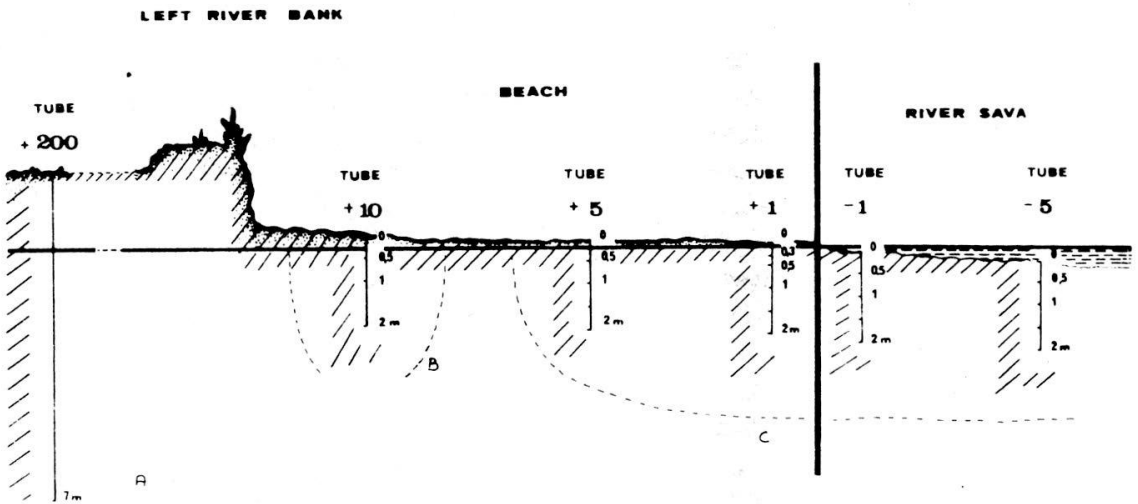

Fig. 1. The river Sava near Zagreb (Jankomir bridge), showing the position of pumping tubes, i.e., sampling points. Numbers indicate their depths and distances from the river edge in meters. 


\section{METHODS}

Samples were taken on 29 June, 17 July, and 3 November 1973, and 17 April 1974 during low water using the Bou-Rouch method. They came from various depths $(0,3-2 \mathrm{~m})$ of crosswise profile including a portion of the left river bank, the beach, and the river bottom (Fig. 1) A Norton pump driven to $7 \mathrm{~m}$ was employed at the same profile, $200 \mathrm{~m}$ from the river.

Determinations of certain bacteriological and chemical parameters of the river water were made, as well as evaluation of the saprobiological conditions of the river and bacteriological, chemical, and faunistic analyses of the interstitial samples. Bacteriological analyses were carried out only in autumn, and more extensive chemical analyses in autumn and spring. All samples taken in 1973 were used for faunistic determinations.

\section{RESULTS, DISCUSSION, AND CONCLUSIONS}

Studies of various relations between the biotopes of subterranean and surface waters were undertaken at a relatively small locality in the Sava river valley near Zagreb. They were carried out on the beach and in the river bottom to $2 \mathrm{~m}$ depth. This was the maximum depth possible with current equipment. At the riverside, samples of water were taken from a depth of $7 \mathrm{~m}$ by a permanently fixed pump, i.e., slightly deeper than the level of subterranean water. The studies included a part of the river bottom and the whole beach of sand and gravel sediments which at high water forms part of a waterside bottom and at low water is exposed. The studies of subterranean water $200 \mathrm{~m}$ away from the river margin were made only once. Accordingly, all areas which, in a vertical and horizontal sense, could be watered by the river were included in the research.

The greater part of the beach closer to the river margin rises so gently that even a slight rise in water level is followed by inflow and affects the substratum. There is more intensive deposition of transported material in this area than in a constantly submerged river bottom, due to a frequent and slow inflow and outflow of river water. This is also indicated by quantities of suspended material at all depths of measurements (Fig. 2).

Comparison of chemical and physical parameters measured simultaneously in the river and interstitial water showed several different ecological areas:

(1) The most distant point from the river $(200 \mathrm{~m})$, where the water is on a depth of $7 \mathrm{~m}$ is situated in an area distinct both in space and some parameters. This location is remarkable for its deficiency of oxygen as well as low temperature. The quantity of $\mathrm{CO}_{2}$ is also considerably less than at ather bores. Alkalinity of 4,1 mval per litre is the lowest recorded in spring, and quantity of ammonia about 10 to 290 times less than in the interstitial water of the beach. This is the phreatic or eustygal area, which differs considerably by its characteristics from others and in which a direct impact of the river could not be defined during the studies (Tab. 1). 
Table 1. Physico-chemical analysis of water from point $+200(7 \mathrm{~m} \mathrm{depth}, 200 \mathrm{~m}$ distance from the river margin).

Water temperature

Dissolved oxygen

Deficiency of oxygen

$\mathrm{BOD}_{2}$

Permanganate number

$\left(\mathrm{KMnO}_{4}\right.$ consumption)

$8,5^{\circ} \mathrm{C}$

Free carbon dioxide

$\mathrm{pH}$

Alkalinity

Chlorides $\mathrm{Cl}$

Ammonia N

$0,8 \mathrm{mg} / 1$

$10,9 \mathrm{mg} / 1$

$4,0 \mathrm{mg} / 1$

$57,1 \%$

Nitrites $\mathrm{NO}_{2}$

$7,9 \mathrm{mg} / 1$

Nitrates $\mathrm{NO}_{3}$

$7,9 \mathrm{mg} / 1$

7,7

Anionic surface-active

agents ("surfactants") TBS

$4,1 \mathrm{mval} / 1$

$14,5 \mathrm{mg} / 1$

$0,01 \mathrm{mg} / 1$

$0,03 \mathrm{mg} / 1$

$0,5 \mathrm{mg} / 1$

$0,0 \mathrm{mg} / 1$

(2) The zone along the water edge, which extends some $5 \mathrm{~m}$ on the beach as well as on the river bottom, is different from the surrounding area. The extent and changes, both in space and time, of physico-chemical and other parameters suggest the existence of various layers. Namely, some parameters at various depths $(0,5,1$ and $2 \mathrm{~m})$ at the same point of measurement, show considerable differences in amount, but a regular increase in these values at each depth in direction from the river edge inland or the reverse is also notable. In addition, seasonal inversions in quantity of oxygen in summer and autumn in a layer at $2 \mathrm{~m}$ depth show that the horizons in consideration have presumably diverse physical structures (granularity). Some indicators, such as more intensive bacteriological activities (heterotrophic bacteria), coliform bacteria, quantity of anionic surface-active agents, presence of populations of the species indicative of a higher degree of organic pollution such as Sphaerotilus natans etc., and the presence of river fauna, demonstrate that the hyporheic zone along the river margin down to $1 \mathrm{~m}$ depth is more influenced by river water and its polluting effect than deeper and more distant zones (Fig. 3, 4, 5, 6; Tab. 2, 3, 4).

(3) Some features of the part of the beach more distant from the river margin (point +10 ) differentiate this zone from the eustygal and from a wider area near the river margin; and various values of the parameters of point +10 and other points closer to the river suggest its characteristic features. Here the quantity of oxygen varies slightly by depth. There are more organic materials here than elsewhere in the alluvium as well as products of mineralization of these organic materials. Perhaps many organic materials and chlorides originate from the surrounding meadows and agricultural areas, and presumably only high water causes a more intensive contact between the river water and the subterranean water of the alluvium. 


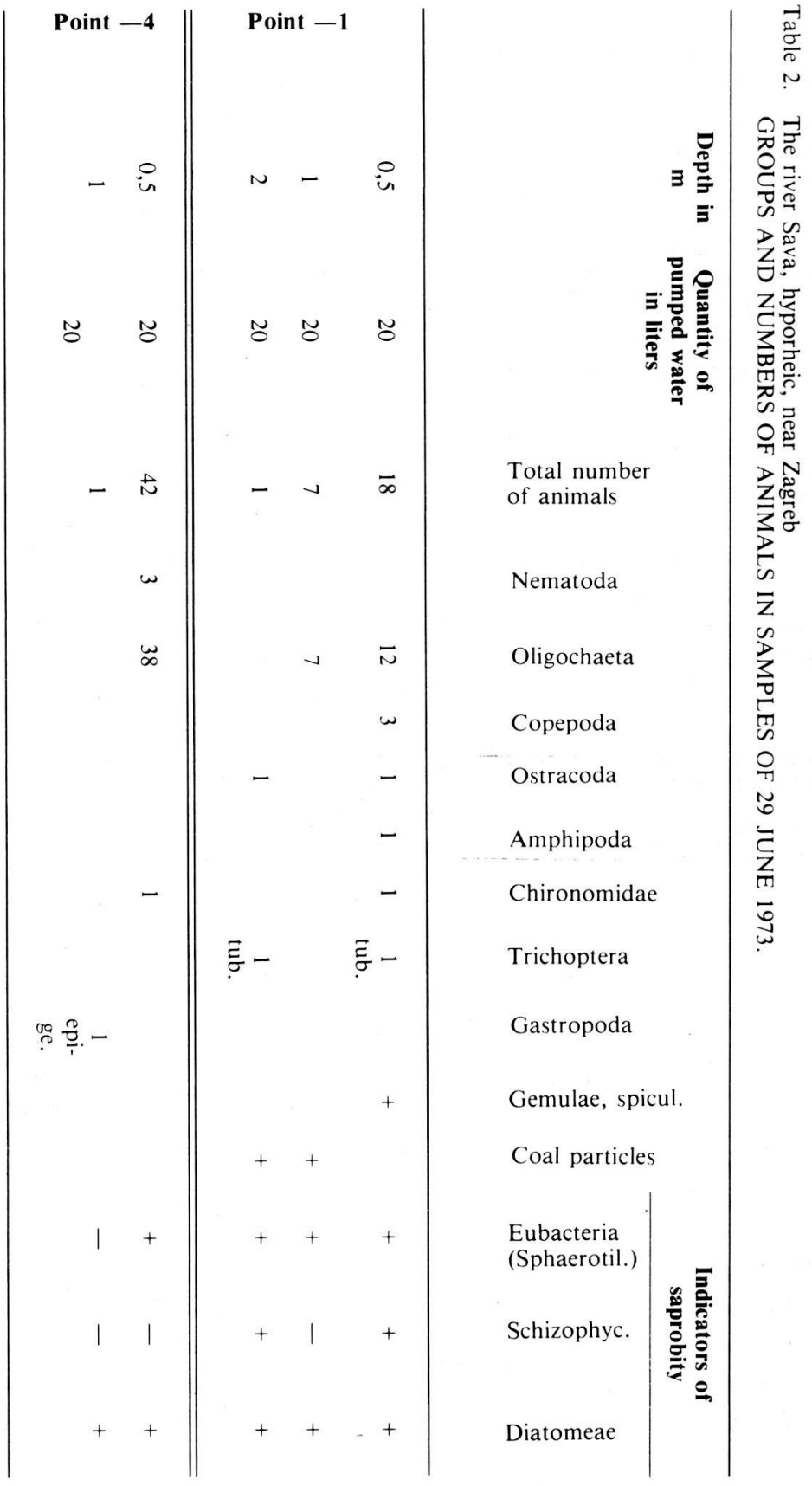


Indicators of pollution like organic compounds, chlorides, nitrates, nitrites, ammonia, and coliform bacteria show that all points on the beach and on the river bottom are subject to the influence of polluted river water at least down to the $2 \mathrm{~m}$ depth. This is confirmed by the presence of particles of coal, Sphaerotilus, and other indicators of saprobity in the deepest examined horizon (Fig. 5, 7, 8, 9, 10, 11; Tab. 2, 3).

The activity of bacteria, evidenced by the presence of products of organic material decomposition and BOD, suggests that the process of autopurification is also performed in the hyporheic. Due to the oxygen demand, down to $1 \mathrm{~m}$ depth, the deficiency of oxygen approaches $99 \%$. In deeper layers, in summer, oxygen almost disappears (Fig. 12).

In comparison with the physically similar habitat by the river Drava near Legrad, studied in the same year (Meŝtrov, et al., 1976a), the fauna of the Sava's hyporheic is not as rich, in the quantitative and qualitative sense (Tab. 4, Fig. 13). Typical subterranean species of Acarina, Isopoda, and Amphipoda

Table 3. The river Sava, hyporheic, near Zagreb GROUPS AND NUMBERS OF ANIMALS IN SAMPLES OF 17 JULY 1973.

\begin{tabular}{|c|c|c|c|c|c|c|c|c|c|c|c|}
\hline & $\begin{array}{c}\text { Depth } \\
\text { in } \\
\text { m }\end{array}$ & $\begin{array}{c}\text { Quantity } \\
\text { of } \\
\text { pumped } \\
\text { water } \\
\text { in } \\
\text { liters }\end{array}$ & 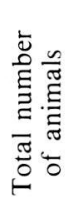 & 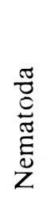 & 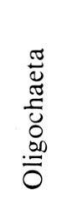 & $\begin{array}{l}\frac{\pi}{0} \\
0 \\
00 \\
00 \\
0\end{array}$ & 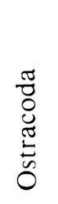 & 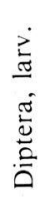 & 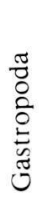 & 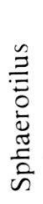 & 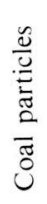 \\
\hline \multirow{3}{*}{$\begin{array}{l}\overline{+} \\
\stackrel{\Xi}{0}\end{array}$} & 0,5 & 40 & 64 & & 61 & 1 & 1 & & 1 & & \\
\hline & 1 & 40 & 7 & 1 & 5 & & 1 & & & & \\
\hline & 2 & 40 & 2 & 1 & 1 & & $\begin{array}{l}3 \times \\
1 / 2\end{array}$ & & & + & + \\
\hline \multirow{3}{*}{ 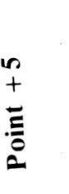 } & 0,5 & 40 & 18 & 1 & 17 & & & & & & \\
\hline & 1. & 40 & 8 & 2 & 2 & & $1 / 2$ & & 4 & & \\
\hline & 2 & 40 & 1 & & 1 & & $\begin{array}{l}3 \times \\
1 / 2\end{array}$ & & & & \\
\hline $\bar{E}$ & 0,5 & 40 & 218 & 3 & 215 & & $\begin{array}{l}5 \times \\
1 / 2\end{array}$ & 1 & & & \\
\hline
\end{tabular}


Table 4. The river Sava, hyporheic, near Zagreb

GROUPS AND NUMBERS OF ANIM-ALS IN SAMPLES OF 3 NOV. 1973.

\begin{tabular}{|c|c|c|c|c|c|c|c|c|c|c|}
\hline & $\begin{array}{l}\text { Depth } \\
\text { in } \\
\text { m }\end{array}$ & $\begin{array}{l}\text { Quantity } \\
\text { of } \\
\text { pumped } \\
\text { water in } \\
\text { liters }\end{array}$ & 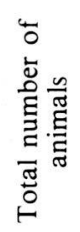 & $\begin{array}{l}\frac{\pi}{0} \\
\stackrel{0}{0} \\
\text { Ẽ } \\
Z\end{array}$ & 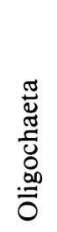 & 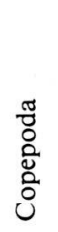 & 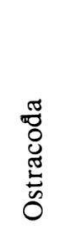 & $\begin{array}{l}\frac{\pi}{0} \\
\frac{0}{Z} \\
\frac{2}{0} \\
\frac{1}{\alpha}\end{array}$ & 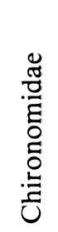 & 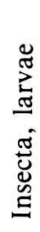 \\
\hline \multirow{4}{*}{$\begin{array}{l}\overline{+} \\
\bar{E} \\
\dot{E}\end{array}$} & 0,3 & 10 & 24 & & 11 & 3 & 1 & & 5 & 4 \\
\hline & 0,5 & 40 & 10 & & 6 & 1 & & & 3 & \\
\hline & 1 & 20 . & 6 & & 4 & 1 & 1 & & & \\
\hline & 2 & 20 & 0 & & & & & & & \\
\hline \multirow{3}{*}{$\begin{array}{l}n \\
+ \\
\pm \\
0 \\
0\end{array}$} & 0,5 & 40 & 6 & & & 5 & & & 1 & \\
\hline & 1 & 20 & 4 & & & & & 1 & 3 & \\
\hline & 2 & 10 & 1 & 1 & & & & & & \\
\hline \multirow{2}{*}{ 音是 } & 1 & 40 & 15 & & 12 & 1 & 1 & & 1 & \\
\hline & 2 & 5 & & & & & $\begin{array}{l}2 \times \\
1 / 2\end{array}$ & & & \\
\hline \multirow{3}{*}{$\frac{T}{0}$} & 0,5 & 40 & 10 & & 2 & & & & 8 & \\
\hline & 1 & 40 & 2 & & 1 & 1 & & & & \\
\hline & 2 & 20 & & & & & $1 / 2$ & & & \\
\hline \multirow{2}{*}{ 를 } & 0,5 & 40 & 6 & & 3 & 2 & & & 1 & \\
\hline & 1 & 40 & 1 & & 1 & & $\begin{array}{l}2 \times \\
1 / 2\end{array}$ & & & \\
\hline
\end{tabular}


are lacking here, which otherwise live in phreatic waters of the Sava valley (Meŝtrov, 1960) and in the hyporheic of the Drava. Perhaps macrocenobionts have a certain role in maintaining the "cleanness" and perviousness of interstices, i.e., circulation of water through them. Eating the infiltrated detritus, they accelerate the process of decomposition and development of a balance in ionic and organic composition of water and open the crevices closed by this detritus (Husmann, 1974, 1975; Bojĉenko, 1975).

Autumnal oxygen enrichment of the deep hyporheic layer of water was not followed by a greater density or a changing composition of stygobiont animal populations. The layers below $1 \mathrm{~m}$ depth in locality studied of the Sava seem to be "ecologically devastated" (Husmann, 1974/75). It is certain that the chronically high degree of pollution with organic and toxic materials causes this phenomenon (Meŝtrov, et al., $1976 \mathrm{~b}, \mathrm{c}$ ). The results of our studies confirm this.

The continuation of comparative ecological research and studies of deeper layers will provide more information and explanations.

Table 5. GROUPS OF ANIMALS SAMPLED IN THE HYPORHEIC OF THE RIVER SAVA near Zagreb and DRAVA near the villages D.Dubrava and Legrad.

\begin{tabular}{|c|c|c|c|}
\hline GROUPS & SAVA & \multicolumn{2}{|c|}{$\begin{array}{c}\text { DRAVA } \\
\text { D. Dubrava Legrad }\end{array}$} \\
\hline Nematoda & + & + & + \\
\hline Oligochaeta & + & + & + \\
\hline Copepoda & + & + & + \\
\hline Ostracoda & + & + & + \\
\hline Amphipoda & $\stackrel{+}{+}$ & - & + \\
\hline Chironomidae & + & + & + \\
\hline Trichoptera & $\stackrel{+}{\text { tub. }}$ & - & - \\
\hline Insecta, others & + & + & + \\
\hline Gastropoda & + & - & + \\
\hline (Sphaerotilus) & + & - & - \\
\hline Ciliata (colon.) & - & - & + \\
\hline Hydrozoa & - & + & + \\
\hline Acarina & - & - & + \\
\hline Isopoda & - & - & + \\
\hline Collembola & - & - & + \\
\hline Coleoptera & - & - & + \\
\hline $\begin{array}{l}\text { Average of animals } \\
\text { per liter }\end{array}$ & 0,63 & 1,3 & 2,2 \\
\hline $\begin{array}{l}\text { Degree of } \\
\text { saprobity }\end{array}$ & $\alpha-\mathrm{m}$ & $\beta-\mathrm{m}$ & $x-m$ \\
\hline
\end{tabular}




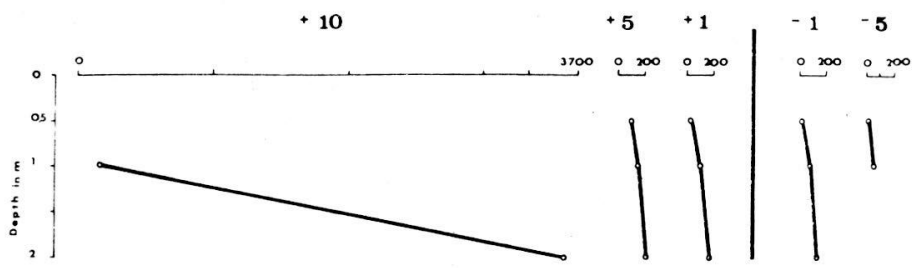

Fig. 2. Suspended matter in hyporheic water (as $\mathrm{mg} / 1$ of residue on evaporation).

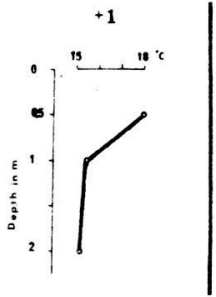

4. 2ง.
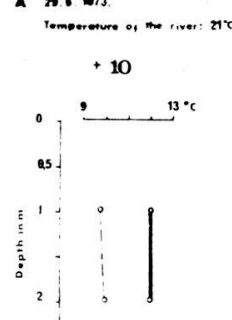

c $\quad-311973$

Fig. 3. Temperature of hyporheic water.

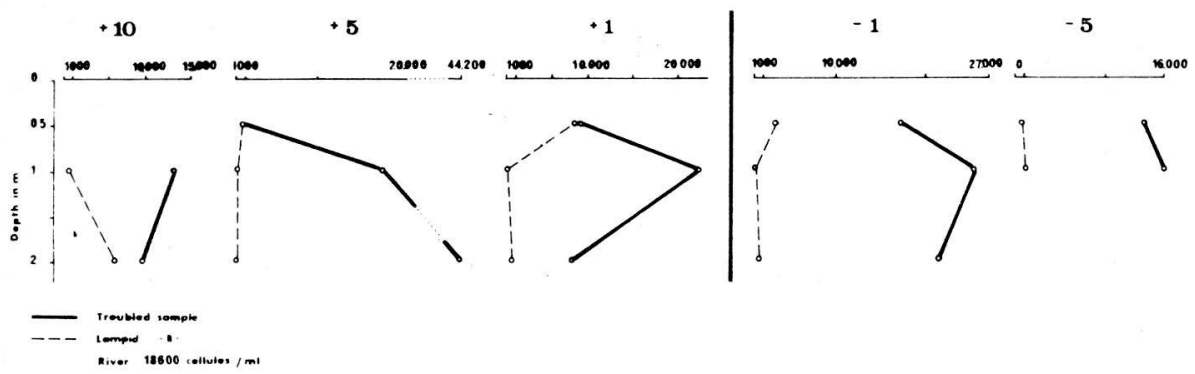

Fig. 4. Number of heterotrophic bacteria in $1 \mathrm{ml}$ of hyporheic water. 


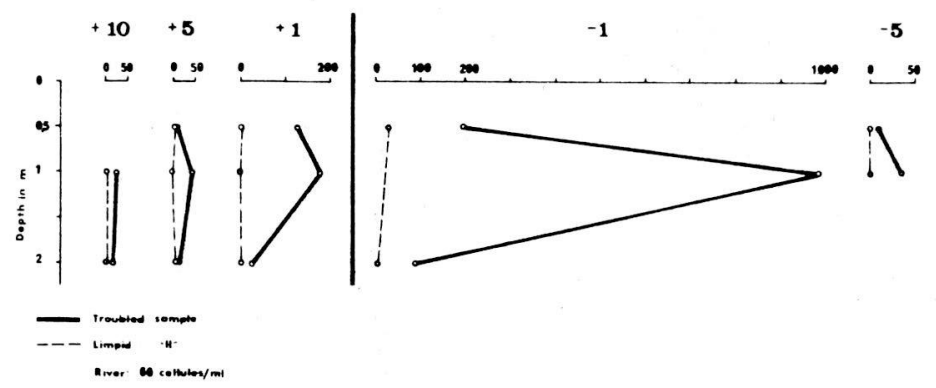

Fig. 5. Number of Escherichia coli cells in $1 \mathrm{ml}$ of hyporheic water.

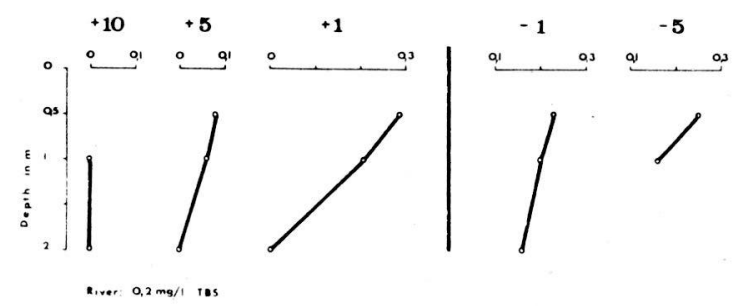

Fig. 6. Anionic surface-active agents ("Surfactants") as mg/1 TBS in hyporheic water.
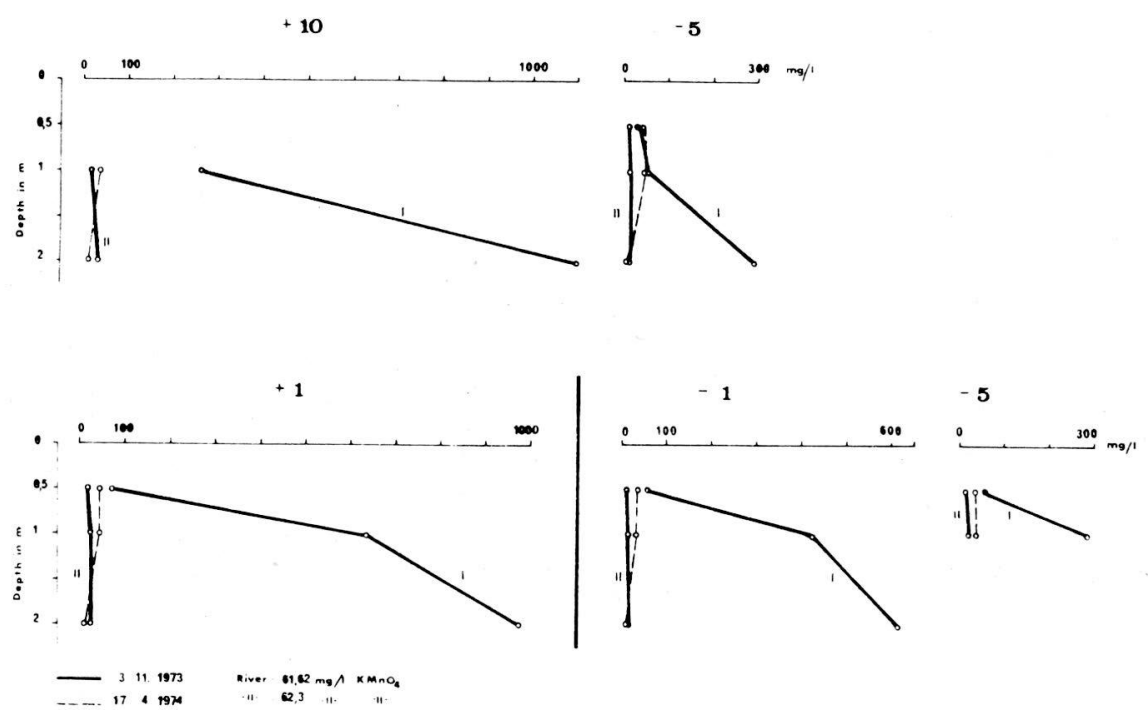

Fig. 7. Permanganate number or $\mathrm{KKnO}_{4}$ consumption, in $\mathrm{mg} / 1$. 


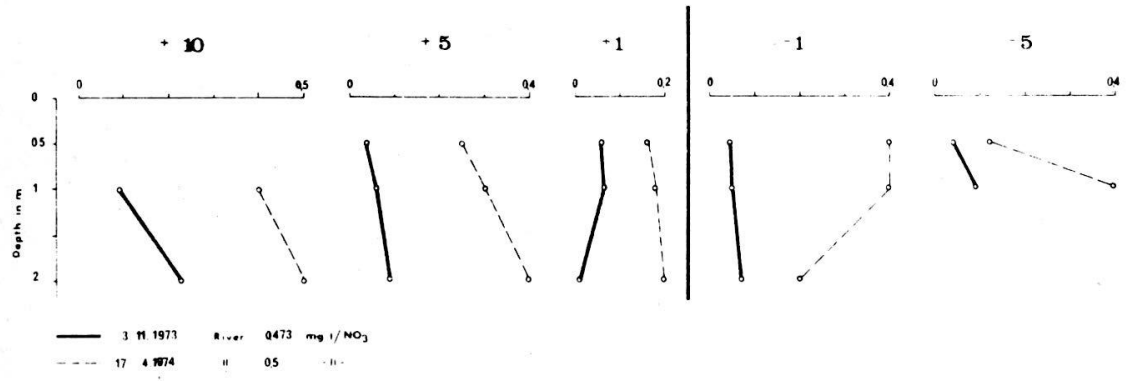

Fig. 8. Nitrates in hyporheic water, as $\mathrm{mg} / 1 \mathrm{NO}_{3}$.

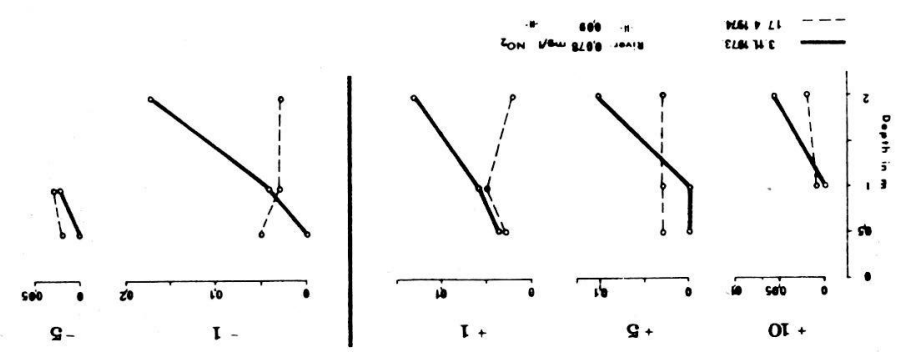

Fig. 9. Nitrites in hyporheic water, as $\mathrm{mg} / 1 \mathrm{NO}_{2}$.

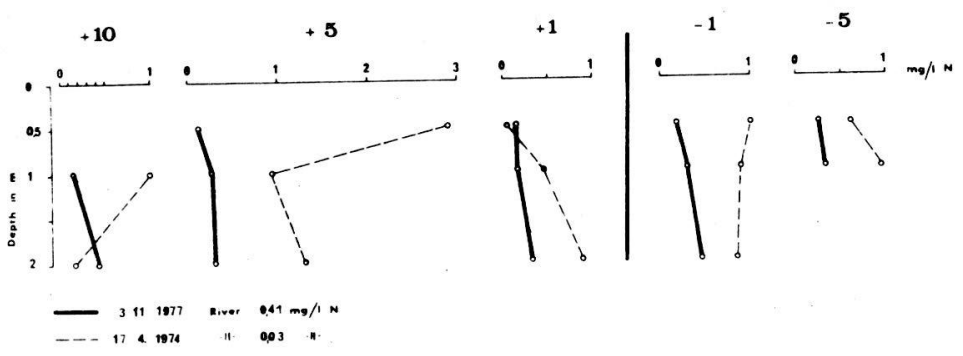

Fig. 10. Ammonia in hyporheic water as $\mathrm{mg} / 1$ ammonia $\mathrm{N}$. 


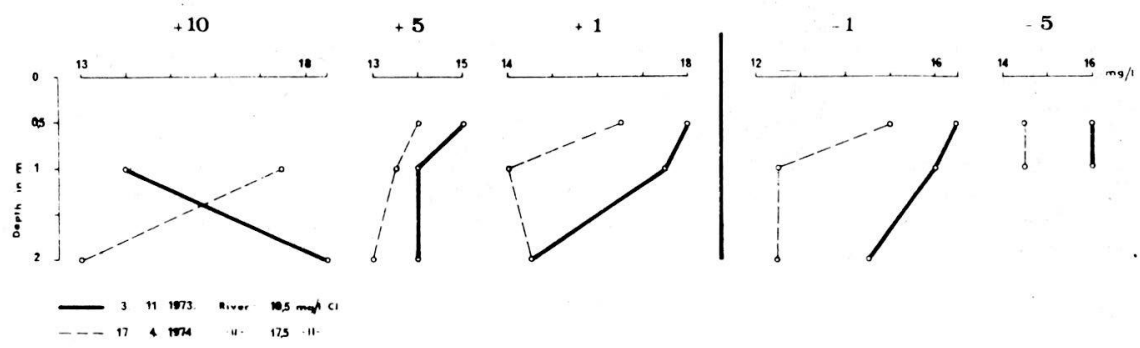

Fig. 11. Chlorides in hyporheic water as $\mathrm{mg} / 1 \mathrm{Cl}$.

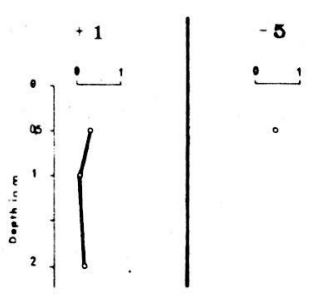

A. 29.1973
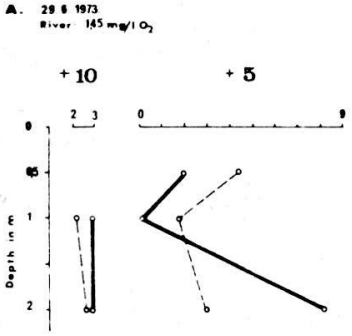

c $\quad 3.111973$ niver $4 \mathrm{mg} / \mathrm{l} \mathrm{O}_{2}$

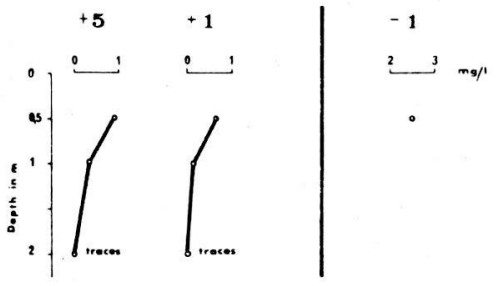

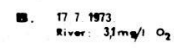

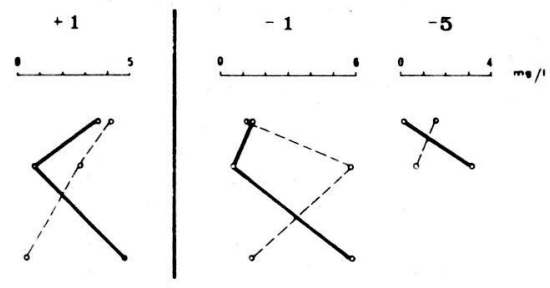

Fig. 12. Quantity of dissolved oxygen in hyporheic water, in $\mathrm{mg} / 1$.

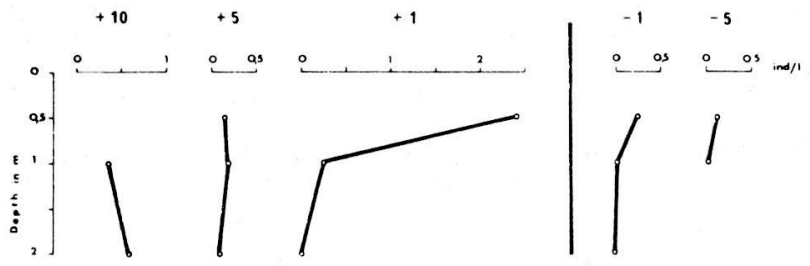

Fig. 13. Number of animals in 1 liter of pumped hyporheic water. 


\section{RÉSUMÉ}

Des recherches présentant à la fois un intérêt fondamental et une importance pratique ont été effectuées sur les eaux souterraines interstielles (hyporhéique) s'écoulant le long de la vallée alluviale d'une rivière polluée: la Save.

En comparant les propriétés physiques, chimiques, bactériologiques, saprobiologiques, de même que les faunes de la rivière de surface et de son écoulement hyporhéique, à des saisons différentes, on peut rechercher quelle est leur influence mutuelle. Les résultats obtenus montrent que l'influence de la pollution de l'eau de la rivière sur l'eau hyporhéique de son lit se fait sentir jusqu'à une profondeur minimale de deux mètres.

\section{REFERENCES}

BOJĈENKO, M.M. 1975. O formirovanii kacestva vodi gidrobiontami. Nauc.dokl.viss.skoli Biol.n., 4,74-77.

DANIELOPOL, D.L. 1976. The distribution of the fauna in the interstitial habitats of riverine sediments of the Danube and the Piesting (Austria) Int.J.Speleol. 8,23-51.

GIAMMONA, Ch.P. 1973. Fluorescent Dye Determination of Groundwater Movement and Contamination in Permeable Rock Strata.Int.J.Speleol. 5,201-208.

HUSMANN, S. 1964. Morphologische, ökologische und verbreitungsgeschichtliche studien über die Bathynellen (Crustacea, Syncyrida) des Niederrhein-Grundwasserstromes bei Krefeld. Gewässer und Abwässer 37/38,46-76.

HUSMANN, S. 1968. Langsamfilter als Biotopmodelle der experimentalökologischen Grundwasserforschung. Gewässer und Abwässer 46,20-49.

HUSMANN, S. 1971. Die gegenseitige Ergänzung theoretischer und angewandter GrundwasserLimnologie; mit Ergebnissen aus Wasserwerken Wiesbadens. Die Sicherstellung der Trinkwassersorgung Wiesbadens. Stadtwerke Wiesbadens AG.

HUSMANN, S. 1974. Die ökologische Bedeutung der Mehrzellerfauna bei der natürlichen und künstlichen Sandfiltration. Künstliche Grundwasseranreicherung am Rhein. Wissenschaftliche Berichte über Untersuchungen u. Planungen der Stadtwerke Wiesbaden AG, 2,173-183.

HUSMANN, S. 1974/75. Versuche zur Erfassung der vertikalen Verteilung von Organismen und chemichen Substanzen im Grundwasser von Talauen und Terrasen; Methoden und erste Befunde. Int.J.Speleol. 6,271-302.

HUSMANN, S. 1975. Die Schotterufer des Niederrheins bei Krefeld:abwasserkranke Biotope mit gestörter Uferfiltration. Gewässer und Abwässer 57/58,7-26.

LÜPKES, G. 1976. Die vertikale Verteilung von Ciliaten im Stygorhithral der Fulda (Beitrag zur Kenntnis mesopsammaler Ciliaten in Fliessgewässern). Int.J.Speleol. 8,127-133.

MEŜTROV, M. 1960. Faunistiĉko-ekoloŝka i biocenoloŝka istraẑivanja podzemnih voda savske nizine.Biol.glasnik 13,73-109.

MESTTROV, M., R. LATTINGER-PENKO, and V. TAVĈAR 1976a. La dynamique de population de l'Isopode Proasellus slavus ssp.n. et les larves de Chronomides dans l'hyporheique de la Drave du point de vue de la pollution. Int.J.Speleol. 8,157-166.

MEŜTROV, M., I. DEŜKOVIĆ, and V. TAVĈAR 1976b. Saprobiological and physicochemical researches of the river Sava in the course of several years. Bull.sci.21,7-9,145146.

MESTTROV et al. 1976. Oekologische Untersuchungen der Flusstrecke des Flusses Sava stromabwärts von Zagreb (Oborovo-Tiŝina) I. Die Gestaltung und Anrodnung von Biozönozen und physich-chemiche Eigenarten des Flusses Sava.Bull.sci.Sect.A Yougosl. 21,10-12,205-206.

RITTERBUSCH, B. 1976. Untersuchungen zur Funktion des Mesopsammon bei der Reinigung von infiltrirtem Oberflächenwasser. Int.J.Speleol. 8,185-193.

SPANGENBERG, H.-J. 1973. Faunistich-ökologische Untersuchungen and Gewässern von Gipshöhlen und im Grundwaser des Südharzes und Kyffhäusers. Int.Revue ges.Hydrobiol. $58,4,501-542$.

- Certain chemical, bacteriological, faunistic and field studies and determinations have been performed respectively by: Dr. I. Habdija, Dr. B.Stilinović and Dr. V. Tavcar. 